\title{
Biotic homogenization and alien bird species along an urban gradient in South Africa
}

\author{
Berndt J. van Rensburg*, Derick S. Peacock, Mark P. Robertson \\ Department of Zoology and Entomology, Centre for Invasion Biology, University of Pretoria, Pretoria 0002, South Africa
}

\section{A R T I C L E I N F O}

\section{Article history:}

Received 10 July 2008

Received in revised form 7 May 2009

Accepted 8 May 2009

Available online xxx

\section{Keywords:}

Acridotheres tristis

Alien

Birds

Biotic homogenization

Gradient of urbanization

Common Myna

\begin{abstract}
A B S T R A C T
Similar to the process seen in invasion biology, urbanized environments lead to biotic homogenization with a few species, often alien, dominating the urban habitat. We investigated avian communities across an urban gradient in Pretoria (South Africa). We defined three urbanization zones: urban, suburban and semi-natural, based on land-cover. We conducted point counts of all species at each of 13 sites in these zones over a 4-month period. We found significantly more species in the semi-natural zone than the urban zone but abundance was significantly lower in semi-natural than urban. The increase in abundance was mainly as a result of alien species with the three most abundant species in the urban zone being all alien. Semi-natural contained fewer alien species than urban and significantly fewer than suburban. The Common Myna Acridotheres tristis was the only alien species that was observed in all three urbanization zones and was the second most abundant species in the suburban and urban zones. Our study supports the process of biotic homogenization, where an increase in alien species occurs in the urban compared to semi-natural zone. Although the suburban zone made an important contribution towards native bird abundance in a larger city environment, this environment was also an important environment for alien species, especially for the Common Myna.
\end{abstract}

(c) 2009 Elsevier B.V. All rights reserved.

\section{Introduction}

As humans are largely responsible for biological invasions (Chapin et al., 2000), and with the growing human population in most parts of the world (Cincotta et al., 2000), there are major challenges in reducing the rate at which ecosystems are being altered due to biological invasions and human activities such as urbanization. Such alterations often lead to a situation in which a small number of species that are well adapted to human-dominated landscapes, and often highly successful alien invaders (see Clergeau et al., 2006; McKinney, 2006; Kark et al., 2007), replace a wider range of native species. This pattern, termed biotic homogenization, has been shown in several regions across the globe (e.g., Clergeau et al., 2006; McKinney, 2006) and is known to reduce the resilience of ecosystems to environmental change. Following Blair's (1996) key study conducted in Northern California, the bird community is usually (i) dominated by urban avoiders (mostly native species only) in relatively undisturbed areas outside the city which consists mainly of native vegetation, (ii) followed by a highly species rich community termed suburban adapters, usually both native and

\footnotetext{
* Corresponding author. Tel.: +27 012420 4627; fax: +27 0123625242.

E-mail addresses: bjvanrensburg@zoology.up.ac.za (B.J. van Rensburg), faansiep@telkomsa.net (D.S. Peacock), mrobertson@zoology.up.ac.za (M.P. Robertson).
}

alien species, in environments with intermediate levels of urbanization, and finally, (iii) urban exploiters, consisting of a small number of species, mainly alien, in the most urbanized areas such as city centres.

Although studies on alien birds and their impacts on native bird species have received much needed attention in recent years (see e.g., Komdeur, 1996; Blackburn and Duncan, 2001; Duncan et al., 2003; Koenig, 2003; Birdlife International, 2004; Smith, 2005), more research on this topic is needed. For example, Reino and Silva (1996) indicated that, in recent years, alien birds in the Mediterranean Basin have shown a significant increase in both their numbers and geographical range sizes, but with few scientific studies recording these changes and related impacts. More specifically, concerns have been expressed by Feare and Craig (1998) that the Common Myna Acridotheres tristis, an invasive alien starling (family: Sturnidae) may pose a threat to indigenous birds and other biodiversity due to substantial increases in the population density and global geographical spread of this species in recent years. This species is reported to be one of the most successful alien invasive birds globally (Lowe et al., 2000) and also in South Africa (Peacock et al., 2007).

This study attempts a whole-community synthesis (Blair, 2004), taking into account multiple species, their interspecific relationships, and spatial and environmental variables. This study assesses the occurrence of alien bird species in relation to habitat parameters at the local scale and should be treated as a baseline for further 
studies. Documenting demographic trends and land-cover associations displayed by alien bird species, and comparing such trends to the qualities and preferences of indigenous species at the local scale is an important first step in mitigating any future potential negative effects resulting from biological invasions. This is true especially in regions lacking reliable data on the ecology of the species in question. For example, in South Africa, a study conducted by Liversidge (1975) is the best reference currently available to indicate a possible displacement of other species by Common Mynas at the local scale (see Hockey et al., 2005). The Liversidge study was conducted nearly 10 years before the Common Myna became established in our study area (Peacock et al., 2007) and therefore indicates the lack of baseline data in the region.

Because studies examining responses of avian communities to environmental variables in urban areas are generally not directly comparable to studies conducted in natural or semi-natural habitats, a popular research approach has been to investigate avian community composition along a gradient of urbanization (Clergeau et al., 1998; Bowman and Marzluff, 2001; Fernandez-Juricic, 2001; Maestas et al., 2003). In this way an attempt can be made to identify some predictable trend of ecological succession along such a gradient, within a species-specific, guild-level or whole-community framework.

Based on a gradient of urbanization identified in the Pretoria region, the capital city of South Africa, we aimed to examine whether biotic homogenization within the bird community is indeed taking place within the wider urban exploiter, adapter and avoider framework (see Blair, 1996; Kark et al., 2007), and if so, define which species belong to each category. We examine these trends for three groups of birds: all species, alien species and the Common Myna. We propose and test the following hypotheses.

\section{All species: There will be an increase in biotic homogenization} with an increase in the level of urbanization.

2. Alien species: Alien species richness and abundance will be higher in the urban exploiter community compared to the avoider community.

3. Common Myna: Compared to all the alien species examined, the Common Myna will be the most dominant (abundance and spatial distribution) species along the urbanization gradient.

As in most cities, Pretoria's land-cover varies from high-rise offices and apartment buildings in the city centre, through residential suburbs with schools, universities and urban green areas within the city limits, to stock and crop farming agricultural land and smallholdings at the city's edge and semi-natural vegetation outside the city limits. The Pretoria region is therefore an ideal study area with its well defined urbanization gradient. The region also has well established alien bird populations, and is home to approximately 2.0-2.2 million people living at an average density of approximately $946-2389$ people $/ \mathrm{km}^{2}$ (Anon., 2001). In addition, this study will address some of the geographical and taxonomic biases occurring in invasion biology, as no detailed studies have focused on a particular invasive bird species in Africa (Richardson and Pyšek, 2008).

\section{Methods}

Pretoria $\left(25^{\circ} 44^{\prime} \mathrm{S} ; 28^{\circ} 11^{\prime} \mathrm{E}\right)$ is situated in a temperate to subtropical transitional region that experiences a summer rainfall regime, receiving its main annual precipitation from October to April. The mean annual precipitation is $674 \mathrm{~mm}$, with a monthly maximum of $136 \mathrm{~mm}$ in January, mostly in the form of convectional thundershowers. The city experiences warm summers (range: $2-36{ }^{\circ} \mathrm{C}$; average: $12-29^{\circ} \mathrm{C}$ ) and mild to cold winters (range: $-6^{\circ} \mathrm{C}$ to $31^{\circ} \mathrm{C}$; average: $5-22^{\circ} \mathrm{C}$ ). The annual average daily temperature is $12-25^{\circ} \mathrm{C}$ (South African Weather Service, http://www.weathersa.co.za/Climat/Climstats/PretoriaStats.jsp).

The city lies in between a series of parallel ridges at an altitude of 1200 and 1542 m.a.s.l. at the interface of lower-lying, subtropical 'Bushveld' savanna vegetation and higher-lying, temperate 'Highveld' grassland. Much of the original pristine habitat has been transformed and in terms of land-cover the region is immensely diverse, which results in an outstandingly diverse avian community. Annual surveys by BirdLife Northern Gauteng have identified as many as 450 regularly occurring species, in addition to 50 erratic vagrants, occurring within a $100-\mathrm{km}$ radius of the city (Marais, 2004). This combined total of around 500 species represents $c a$. $52.6 \%$ of southern Africa's known bird species.

Surveys were conducted using a point count method (Bibby et al., 1992; reviewed by Buckland et al., 1993). In consideration of the possible interspecific interactions among species all indigenous and alien species were surveyed in order to obtain a holistic, community-based ecological view (Blair, 2004). To ensure sufficient coverage of survey sites that were representative of the complete urbanization gradient, the study area (approximately $19 \mathrm{~km}^{2}$ ) was subjectively stratified into three zones of urbanization, namely urban, suburban and semi-natural. Within each zone, 13 survey sites from a total of 40 potential sites were identified as representative of the given urbanization zone using an objective approach by considering the land-cover within a 250 -m radius drawn around each site following Lim and Sodhi (2004). Land-cover classification was performed by visual means using the 'Google Earth ${ }^{\mathrm{TM}}$ mapping service' (http://earth.google.com), a software package that provides high-resolution digital satellite imagery that is updated regularly ( $<3$ years old). Using these true-colour images, the location of each site was plotted and verified by their coordinates on a 1:50,000 topographical map sheet. The $250 \mathrm{~m}$ circle was divided into 491 grid squares of approximately $20 \mathrm{~m} \times 20 \mathrm{~m}$ areal extent (depending on the site's altitude). Each grid square was then visually classified into one of three land-cover classes, viz. urban, suburban and seminatural. A site was assigned to a particular urbanization zone if it was dominated ( $>50 \%$ ) by the relevant land-cover class. In addition, sites were selected to ensure at least $100 \mathrm{~m}$ visibility in $270^{\circ}$ and were therefore biased towards visually open locations (e.g., parks, sports grounds, car parks and natural sites with open-structured vegetation). Finally, sites were spaced a minimum distance of $300 \mathrm{~m}$ from each other to reduce the possibility of pseudo-replication and areas with abnormally high avian biomass as a result of localised resources (e.g., poultry farms, cattle feeding lots, sewerage plants, bird feeding stations, known communal roosts) were also avoided.

The focus of this study was on resident bird species, and was thus conducted from May to August 2006, terminating well before the main influx of migrants in October-November (Harrison et al., 1997) and excludes both seasonally present breeding visitors (e.g., cuckoos, certain swallows and swifts) or 'wintering' non-breeders (e.g., warblers and flycatchers). Each of the 39 points was visited once a month for 4 months to account for short-term fluctuations in bird numbers. On each visit, all birds recorded within a specified radial distance from a fixed point were counted, and placed within one of five pre-defined distance bands (0-20, 20-30, 30-40, 40-50 and 50-65 m; following methodology suggested in Buckland et al., 1993) that were standard across all sites and urbanization zones. As the likelihood of detection is disproportionately greater closer to the observer (which is accounted for by the statistical software used), a larger first band was selected, but still at a size affording a $100 \%$ detection probability-one of the primary prerequisites for accurate density modelling when using distance sampling (Buckland et al., 1993).

After the elapse of an initial $2 \mathrm{~min}$ period to allow disturbed birds to become accustomed to the presence of the observer, all birds (of 
all species) detected within the abovementioned $65 \mathrm{~m}$ radius in a period of $8 \mathrm{~min}$ were counted and their position in one of the five distance bands noted. Flying birds such as Hirundinidae, Apodidae, Falconidae and Accipitridae were ignored except if it was clear that they originated from the area (e.g., birds taking flight from, or landing in the point count radius) or were otherwise clearly associated with the area (e.g., flying birds milling about their evening roosts). Counts were not conducted on days with adverse weather conditions and to minimise inter-observer variability, all counts were conducted by one observer. All counts were conducted within a 3-h period in the early morning or late afternoon (controlling for changes in sunrise and sunset times) and the same site was visited alternately in the morning and evening on successive sampling occasions.

\subsection{Species density and richness analysis}

Sample-based rarefaction curves, calculating species density values, were compiled for each of the urbanization zones to establish sampling representivity (Gotelli and Colwell, 2001). These curves compare different data sets in terms of species density (the number of species per unit area) (Gotelli and Colwell, 2001; Magurran, 2004). The observed rarefaction curves were calculated using a moment-based interpolation method (Mao Tau) with EstimateS v. 8.0 (http://viceroy.eeb.uconn.edu/estimates; Colwell, 2005). Calculating these curves requires no resampling and has been shown to be as accurate as the traditional resampling method (Colwell et al., 2004). Sampling is considered to be adequate if the observed rarefaction curve approaches an asymptote (Longino et al., 2002) or if it converges closely with an appropriate richness estimator. The Jacknife2 richness estimator (Magurran, 2004) was used because, unlike most other estimators, it does not require species to be independent, sampling points to be compositionally similar and data can have either a parametric or non-parametric distribution. The estimated richness values for each zone was calculated without resampling as this approach produces more accurate richness estimates compared to a sampling approach (Colwell, 2005).

To compare the species richness values of sites between urbanization zones, rarefaction curves must be scaled by number of individuals (calculating species richness) and not by number of samples (calculating species density). The sample-based data were therefore scaled by the number of individuals from which individual-based rarefaction curves were computed in EstimateS using the Coleman method (Coleman, 1981). Thereafter, the curves were rarefied to the lowest number of individuals recorded in a zone to ensure valid comparisons of species richness between different zones (Gotelli and Colwell, 2001; Magurran, 2004).

Species richness (estimated based on Jacknife2) and abundances for all species, native species, alien invasive species, and Common Mynas were compared between the urbanization zones using Analysis of Variance and Tukey HSD tests.

\subsection{Population density analysis based on distance survey intervals}

Population density estimations and modelling of the detection function (i.e., decreasing probability of detection with increasing distance from the observer) were performed using the DISTANCE software package (Thomas et al., 2005), with post-stratification performed across species and urbanization zones. Due to the relatively low sample size of 13 survey sites per urbanization zone (a pilot study indicated that 40 sites are needed for accurate density modelling), density estimates were only calculated for those species where more than 60 individuals were recorded. Following Buckland et al. (1993), population density estimates for species with 20-60 records are considered moderately reliable, but 60 or more records
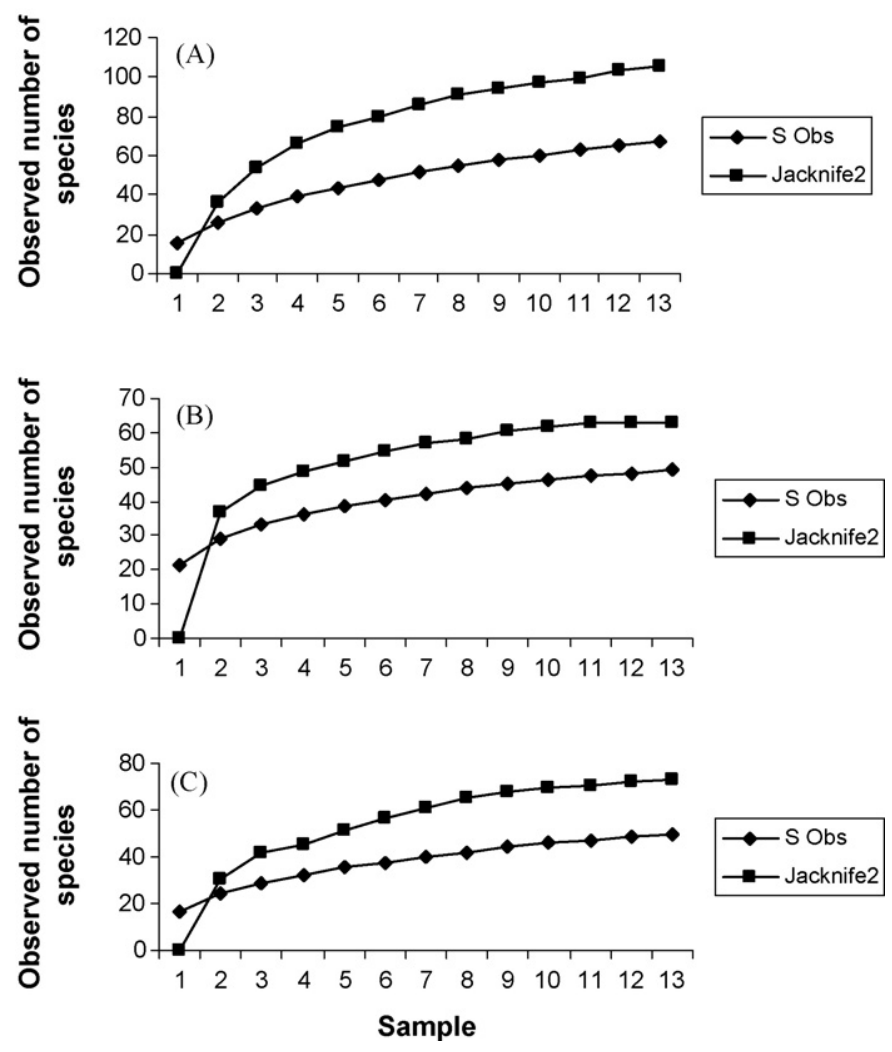

Fig. 1. Avian species rarefaction curves (sampled-based; Mao-Tau (Gotelli and Colwell, 2001)) based on the observed number of species (S Obs) and Jacknife2 richness estimators (Magurran, 2004) for (A) semi-natural, (B) suburban, and (C) urban sites.

are considered a sufficient sample size for accurate density modelling. Subsequently, population density estimates for comparisons among the three urbanization zones were based on 16 species only.

\section{Results}

Although sample-based rarefaction curves started flattening off for all three urbanization zones (Fig. 1), the sampling effort of 13 survey sites did not allow these curves to reach an asymptote nor did they converge closely with the observed Jacknife2 richness estimate. The observed species richness values should therefore be treated with caution and site comparisons between zones should rather be made based on individual-based rarefaction curves (rarefied estimates) and Jacknife2 richness estimates.

\subsection{All species}

Considering all species examined (92 species, 4058 individuals; Appendix A), the semi-natural zone had more species (based on Jacknife2 estimates) than urban and significantly more species than suburban, whereas abundance in urban was higher than suburban and significantly higher than semi-natural (Table 1).

In order to better understand the factors leading to the differentiation of avian communities along the urbanization gradient, all species with more than 10 records $(n=46)$ were ranked according to their abundance in the semi-natural zone (Fig. 2). With the exception of the Terrestrial Crowned Lapwing Vanellus coronatus, the most abundant species in this zone are all predominantly granivorous and social (see Fig. 2 for list of species names). Both in the suburban and urban zones, Crowned Lapwings show similar absolute (but different proportional) abundance to that in seminatural. Cape Sparrows are particularly abundant in suburban areas, 
Table 1

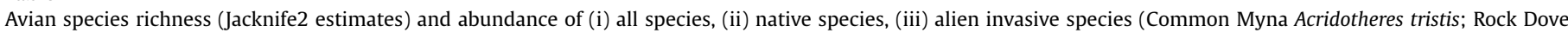
Columba livia; Rose-ringed Parakeet Psittacula krameri; House Sparrow Passer domesticus), and (iv) Common Myna collected in semi-natural, suburban and urban zones.

\begin{tabular}{|c|c|c|c|c|c|c|}
\hline Habitat and bird group & Richness mean \pm S.E. & Abundance mean \pm S.E. & $n$ & $s$ & $S$ & $N$ \\
\hline \multicolumn{7}{|l|}{ All species } \\
\hline & $\left(F_{2,36}=4.271, p=0.022\right)$ & $\left(F_{2,36}=3.958, p=0.028\right)$ & & & & \\
\hline Semi-natural & $75.88 \pm 8.50^{\mathrm{a}}$ & $55.15 \pm 9.56^{\mathrm{a}}$ & 13 & 66 & 105 & 717 \\
\hline Suburban & $50.91 \pm 4.79^{\mathrm{b}}$ & $113.23 \pm 10.71^{\mathrm{ab}}$ & 13 & 45 & 63 & 1472 \\
\hline Urban & $54.21 \pm 5.82^{\mathrm{ab}}$ & $143.77 \pm 36.47^{b}$ & 13 & 39 & 73 & 1869 \\
\hline \multicolumn{7}{|l|}{ Native species } \\
\hline & $\left(F_{2,36}=4.883, p<0.05\right)$ & $\left(F_{2,36}=7.581, p<0.01\right)$ & & & & \\
\hline Semi-natural & $73.48 \pm 8.25^{\mathrm{a}}$ & $51.92 \pm 8.89^{\mathrm{a}}$ & 13 & 64 & 101 & 675 \\
\hline Suburban & $47.02 \pm 4.36^{\mathrm{b}}$ & $93.92 \pm 8.40^{\mathrm{b}}$ & 13 & 42 & 57 & 1221 \\
\hline Urban & $52.66 \pm 5.68^{a b}$ & $54.38 \pm 8.37^{a}$ & 13 & 46 & 69 & 707 \\
\hline \multicolumn{7}{|l|}{ Alien invasive species } \\
\hline & $\left(F_{2,36}=8.464, p<0.001\right)$ & $\left(F_{2,36}=3.656, p=0.036\right)$ & & & & \\
\hline Semi-natural & $2.37 \pm 0.30^{\mathrm{a}}$ & $3.23 \pm 1.20^{\mathrm{a}}$ & 13 & 2 & 3 & 42 \\
\hline Suburban & $4.17 \pm 0.41^{b}$ & $19.31 \pm 3.76^{a}$ & 13 & 3 & 6 & 251 \\
\hline Urban & $2.80 \pm 0.24^{\mathrm{a}}$ & $89.38 \pm 41.31^{b}$ & 13 & 3 & 3 & 1162 \\
\hline \multicolumn{7}{|l|}{ Common Myna } \\
\hline & $\left(F_{2,36}=0.006, p=0.994\right)$ & $\left(F_{2,36}=4.950, p=0.013\right)$ & & & & \\
\hline Semi-natural & $0.93 \pm 0.08^{\mathrm{a}}$ & $3.15 \pm 1.16^{\mathrm{a}}$ & 13 & 1 & 1 & 41 \\
\hline Suburban & $0.92 \pm 0.08^{\mathrm{a}}$ & $12.92 \pm 3.04^{b}$ & 13 & 1 & 1 & 168 \\
\hline Urban & $0.93 \pm 0.08^{a}$ & $8.85 \pm 2.00^{\mathrm{ab}}$ & 13 & 1 & 1 & 115 \\
\hline
\end{tabular}

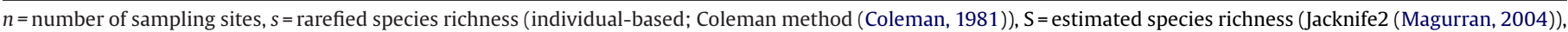

$N=$ total abundance. Means with no letters in common denote significant differences between habitat types of $p<0.05$.

and occur at similar abundances in urban and semi-natural areas. Furthermore, the three common Streptopelia doves as well as the Dark-capped Bulbul Pycnonotus tricolor, showed large increases in abundance in both the suburban and urban zones. Around the middle of the list, several species that are moderately abundant in semi-natural zones are absent from, or occur in low numbers in the other two zones. These species are predominantly grassland specialists (see Fig. 2 for list of species names).

The lower half of the list is dominated by urban and suburban species that were exceedingly rare or absent from semi-natural sites. These follow similar abundance patterns with the exception of: the absence of the African Hoopoe Upupa africana, and Red-headed Finch Amadina erythrocephala from urban sites; the substantially higher abundance of Rock Doves in the urban sites; and finally the presence of Red-winged Starlings Onychognathus morio, and Blue Waxbills Uraeginthus angolensis in urban areas.

Based on population density estimations using the DISTANCE software package, as calculated for only those species for which 60 or more individuals were recorded $(n=16)$, semi-natural areas showed the highest overall bird density ( 54.84 birds/ha), closely followed by urban (54.32 birds/ha). However, semi-natural areas had a lower average cluster density (17.21 clusters/ha) than urban (28.76 clusters/ha), indicating that semi-natural areas have higher average cluster sizes (i.e., more individuals per cluster) than urban. This means that semi-natural areas are characterised by fewer flocks, but more individuals per flock compared to urban. In contrast, suburban areas showed the lowest overall density (43.95 birds/ha) but a cluster density intermediate between those of the other two zones (25.13 clusters/ha). In addition to underlying ecosystem processes that could account for these changes in population density, for example predation and intraspecific competition, these patterns, could partly be explained by the influence of the detection probability curve. This curve describes how the probability of detecting an animal decreases with increasing distance from the observer. That is, the three zones are subject to different detection functions measured as $p$ (detection) values (i.e., the probability of detecting an object in a defined area) and EDR (effective detection radius) values; semi-natural $p=0.73$ (EDR $55.20 \mathrm{~m}$ ); suburban $p=0.72$ (EDR $55.02 \mathrm{~m}$ ) and urban $p=0.67$ (EDR $51.93 \mathrm{~m}$ ). However since the values between the three zones are very similar, we expect that the influence of these different detection probability measures should be minimal.

\subsection{Alien species}

Semi-natural contained fewer alien species (based on Jacknife2 estimates) than urban and significantly fewer than suburban. Abundance in urban was significantly higher than suburban and semi-natural, for the alien species (Common Myna, Rock Dove Columba livia, Rose-ringed Parakeet Psittacula krameri, House Sparrow Passer domesticus) examined (Table 1). The unusually high abundance of alien species in urban areas is at least in part as a result of dense flocks of Rock Doves that are a constant feature of the city's central business district (and indeed in most major cities around the world). Nevertheless, considering all the species recorded 10 or more times during the survey period (both native and alien), the three most abundant species in the urban zone are all invasive aliens (see Fig. 2).

\subsection{Common Myna}

Compared to all the alien species examined, the Common Myna was the only species that was observed in all three urbanization zones (Fig. 2). The myna was the only alien species occurring in semi-natural, and compared to all the species examined, ranks as the fifth most abundant species in this zone (Fig. 2). Next to the Rock Dove in the urban zone, the myna showed the highest alien abundance value in the suburban and urban zones (Fig. 2). The myna reached its highest abundance value in suburban and this was significantly higher than semi-natural with abundance values in urban being intermediate between the two zones (Table 1).

Based on the 324 Common Myna records, population density values for this species were highest in suburban at 3.25 mynas/ha (95\% CI range 2.10-5.02), followed by urban at 2.43 mynas/ha (95\% CI range 1.47-4.02). The average myna population density in semi-natural areas was five and a half, and four times lower compared to suburban and urban densities, respectively, with a value of 0.59 mynas/ha (95\% CI range $0.23-1.52$ ). 

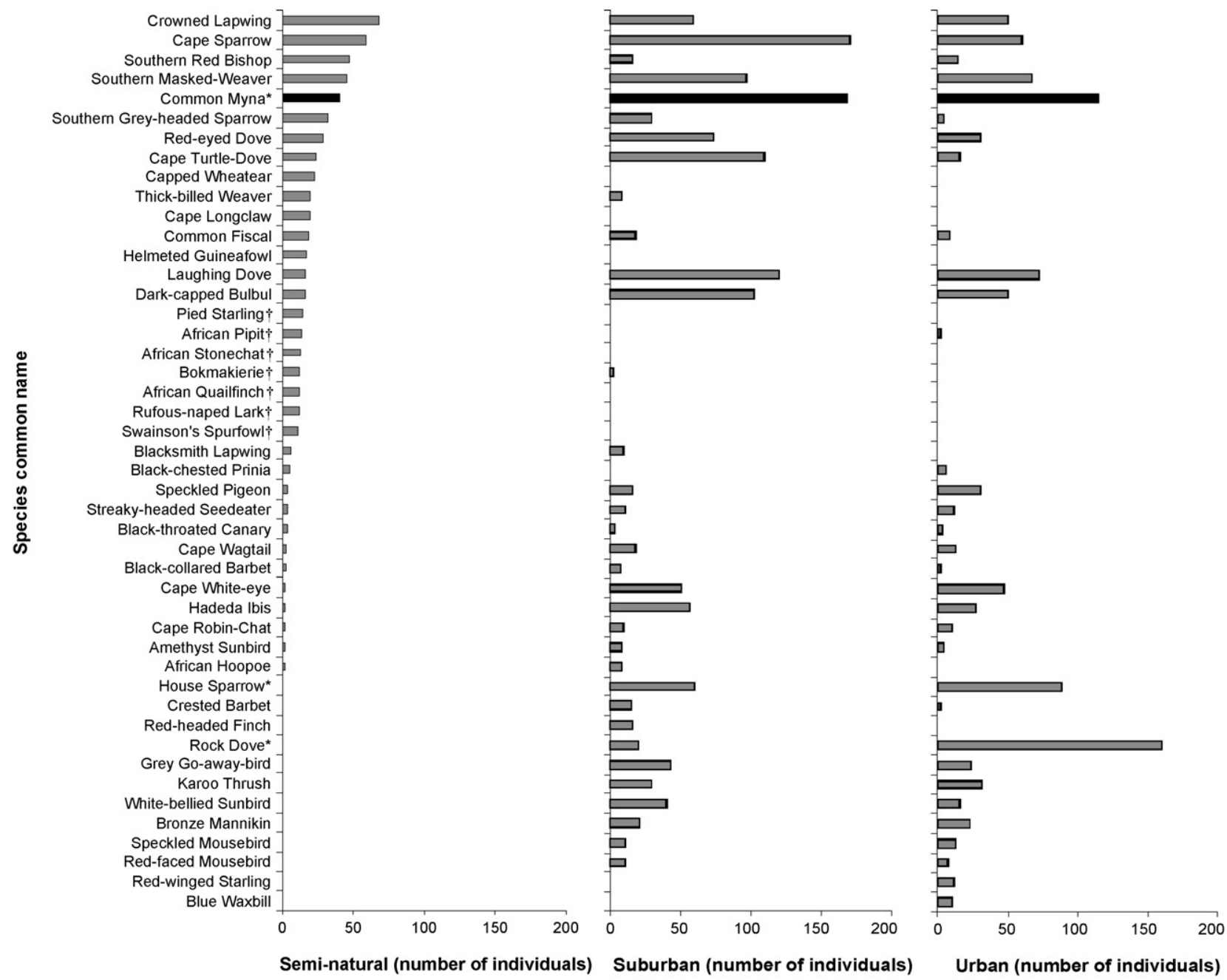

Note: For Rock Dove Columba livia (which was numerically the most abundant species recorded), only 160 records were plotted on the urban graph (out of a total of 959) to optimize legibility. Common Myna Acridotheres tistis is indicated in black; $*$ denotes alien invasive species; $\uparrow$ denotes urban avoiders that are predominantly grassland specialists.

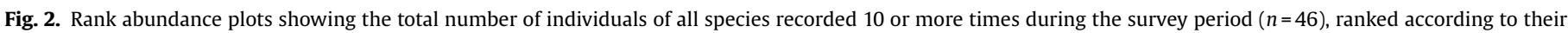
status in the semi-natural zone of urbanization. Scientific names for the species are presented in Appendix A.

\section{Discussion}

Based on this study, we found that the land use changes (especially high water availability and afforestation levels) associated with the urbanization gradient did lead to biotic homogenization within the bird communities examined. This is true for both native and alien species. The significant increase in the abundance of alien species moving from semi-natural to urban is clearly responsible for the overall increase in abundance when considering all native and alien species. That is, when considering the abundance of native species only, the values are very similar when comparing seminatural and urban (Table 1). This result together with fewer native species in urban compared to semi-natural, although not significant (Table 1), suggests an increase in biotic homogenization with an increase in the level of urbanization. Considering all the bird species examined, our study therefore supports the first hypothesis that biotic homogenization will take place along a gradient of increasing urbanization.

Our data further supported the biotic homogenization hypothesis when considering habitat specialist species. While certain native species benefited from the higher levels of urbanization, there is also a clear group of native species, predominantly grassland specialists that could not adapt to the changes in their natural habitat caused by urbanization. Such a decrease in specialist species indicates biotic homogenization (see also Blair, 1996; McKinney, 2002) and include Pied Starling Spreo bicolor, African Pipit Anthus cinnamomeus, African Stonechat Saxicola torquatus, Bokmakierie Telophorus zeylonus, African Quailfinch Ortygospiza atricollis, Rufous-naped Lark Mirafra africana and Swainson's Spurfowl Pternistes swainsonii.

The planting of trees, in a mostly tree-less Highveld (grassland) area (Low and Rebelo, 1996), coupled with extensive irrigation and thus simulating areas with high precipitation, is most likely responsible for several indigenous, anthropophilic species to show marked abundance peaks in the urban and suburban zones while being exceedingly rare or absent from semi-natural sites. Such conditions would be particularly advantageous to species normally associated with wooded areas such as the Crested Barbet Trachyphonus vaillantii, Speckled Mousebird Colius striatus, Grey Go-away-bird Corythaixoides concolor, Ovambo Sparrowhawk Accipiter ovampensis, Cape White-eye Zosterops virens, Karoo (Olive) Thrush Turdus smithi, Cape Robin-Chat Cossypha caffra and White-bellied Sunbird 
Cinnyris talatala. Also, the importance of precipitation as an underlying causation in explaining avian species richness patterns at the broad regional scale across South Africa has been shown by van Rensburg et al. (2002) with precipitation setting limits to primary productivity (see O’Brien et al., 2000).

With semi-natural areas representing significantly lower (i) alien invasive species richness and abundance patterns compared to suburban and urban, respectively, and (ii) Common Myna abundance compared to suburban (and non-significantly lower than urban), it is clear that semi-natural areas do not constitute preferred habitat for these species. This result supports our second hypothesis and Blair's (1996) study with urban exploiters showing a higher dominance of alien species compared to the bird community representing urban avoiders in semi-natural areas. Nevertheless mynas do not completely avoid semi-natural areas, particularly where there is agricultural activity or human habitation in close proximity (Holzapfel et al., 2006).

The invasive alien Common Myna is one of the five most abundant bird species in all the urbanization zones examined (Fig. 2) and showed the third highest frequency of occurrence between survey sites (occurred in 32 of the 39 sites) next to the Southern Masked-Weaver (34 sites) and Dark-capped Bulbul (35 sites; Appendix A). Overall, 36\% of the total bird abundance (i.e., number of individuals recorded) was made up by the four alien species, with myna being the only alien species occurring in all three of the urbanization zones. Our study therefore supports the hypothesis that the Common Myna is the most dominant alien species along the urbanization gradient. Moreover, our study clearly indicates that in the two decades that have elapsed since the myna became established in Pretoria in the 1980s (Tarboton et al., 1987; Peacock et al., 2007), mynas have become a prominent component of the city's urban, suburban and semi-natural avian communities, both numerically and geographically. These results are consistent with broad scale conclusions suggesting that, in the last century, Common Mynas have undergone a remarkable population increase, coupled with a large-scale invasive spread through parts of southern Africa (Peacock et al., 2007).

The life-history traits associated with mynas, such as its omnivorous diet, adaptability to novel environmental conditions and its opportunistic nature have therefore resulted in this species being highly successful in competing with other species (see Kark et al., 2007 for more information on life-history traits related to urban exploiters). Moreover, these traits have resulted in this species being classified as one of the 'World's 100 Worst Invaders' (Lowe et al., 2000). It is one of only three bird species (two of which are starlings) to be included in this list. They are rarely encountered far from human habitation, but do venture further afield on occasion, probably either during post-breeding wandering or during shortterm foraging forays. For example, in the large and relatively pristine Rietvlei Nature Reserve which forms part of the semi-natural zone of Pretoria, mynas were frequently observed associating with Plains Zebra Equus burchelli, possibly catching disturbed insects. They have also been noted to glean ectoparasites from the hides of large herbivores, including dairy cows (D. Weaver, pers. commun.). Such resourceful behaviour might be an important mechanism for their continued spread and colonisation of rural towns in the northern, eastern and central regions of South Africa (see Peacock et al., 2007).

Land-cover variables characteristic of the suburban zone seem to be particularly important in determining myna's local distribution patterns and also that of overall alien invasive species followed by urban and semi-natural land-cover variables. Environments with intermediate levels of urbanization or disturbance, such as the suburban zone, often show species richness peaks (Blair, 1999; Crooks et al., 2004; Shochat et al., 2006) with a community consisting of both native and alien species (Blair, 1996). One would expect urban exploiters to have better breeding opportunities, and thus number of nests, in the urban zone compared to the suburban zone as a result of more buildings and man-made structures in urban areas (Kark et al., 2007). However, myna abundance is highest in the suburban zone most likely as a result of better feeding opportunities in this zone. Also, the sampling design of this study was more sensitive in capturing species abundance values related to feeding activities compared to nesting activities.

Within the suburban zone, mynas' local distribution patterns and densities appeared to be determined to a large extent by the presence of urban green areas (e.g., city parks, sports fields, lawns and large suburban gardens). Similar to some other Eurasian starlings, mynas are adapted for open-bill probing in the grass mat, and thus use lawns, sports fields and irrigated (i.e., relatively soft) substrates for this type of food collection. This preference for areas typically characterised by large irrigated grass lawns in a semiarid region such as South Africa (Schulze, 1997), and extensive afforestation through the planting of trees in a mostly tree-less Highveld (grassland) area (Low and Rebelo, 1996) together with artificial structures such as street lights and buildings that provide nesting and roosting opportunities, mirrors in many ways the species' habitat preference in its native tropical range (Feare and Craig, 1998). This result is consistent with many other semiarid areas of the Common Myna's introduced range (see e.g., Pell and Tidemann, 1997; Yap et al., 2002; Holzapfel et al., 2006).

In conclusion, our data suggest that in the Pretoria region, the continued spread and population growth of the Common Myna are the direct result of anthropogenic land transformation. This suggests that the apparent inverse relationship between alien and indigenous birds may simply be a result of some underlying causal factor associated with anthropogenic transformation, and not necessarily due to the presence of aliens themselves (see also Koenig, 2003 and Smith, 2005 for recent assessments of the impact of the Common Starling Sturnus vulgaris on native holenesting bird species in North-America and Britain). Considering the larger species community examined, our analyses complement those from other studies (Blair, 2001; Lockwood and McKinney, 2002; Crooks et al., 2004) indicating an increase in biotic homogenization as urbanization increases with a lower number of species being able to persist in the highly transformed urban habitat compared to the semi-natural environment. In addition, and similar to the process of invasion biology suggested by Kark et al., 2007, our study highlights the dominance of a few species (all alien) in the urban environment with some species, for example Rock Dove, are nearly entirely dependant on urban resources (see Shochat et al., 2006 for a general description of such species). Of the four alien species recorded, the Common Myna, House Sparrow and Rock Dove are invasive in many parts of the world and are usually associated with humans (Matthews and Brandt, 2004, 2006). The Rose-ringed Parakeet showed the lowest abundance of the four alien species observed but unlike the other alien species it is not listed as invasive by the Global Invasive Species Program (www.gisp.org).

Considering only the native species, the suburban environment made an important biodiversity contribution especially as far as abundance is concerned. The maintenance of more such areas in a larger city environment should therefore be a priority if the aim is to conserve as much of a region's biodiversity as possible. However it is important to note that the suburban environment was also an important environment for alien species, especially for the Common Myna. Therefore, given the remarkable population increase of mynas in southern Africa (Peacock et al., 2007), and their known negative effects on the environment in some parts of the world (e.g., dispersal of alien invasive shrub species-Fleischmann, 1997; reducing the breeding success of hollow-nesting birds-Komdeur, 1996; Pell and Tidemann, 1997; agricultural pests-Kannan and James, 2001), careful documentation and monitoring of any new 
occurrences of Common Mynas in semi-natural areas are needed and should be ongoing in order to assist with the potential future management of this species.

\section{Acknowledgement}

The authors gratefully acknowledge financial support by the DST-NRF Centre of Excellence for Invasion Biology (CIB) and the University of Pretoria.

\section{Appendix A. The total number of bird species and individuals recorded in each urbanization zone. SUM = sum of the survey sites in which a species was recorded. Alien invasive species are indicated in bold.}

\begin{tabular}{|c|c|c|c|c|c|}
\hline Species & $\begin{array}{l}\text { Species } \\
\text { common name }\end{array}$ & SUM & Semi-urban & Suburban & Urban \\
\hline $\begin{array}{l}\text { Acridotheres } \\
\text { tristis }\end{array}$ & $\begin{array}{l}\text { Common } \\
\text { Myna }\end{array}$ & 32 & 41 & 168 & 115 \\
\hline $\begin{array}{l}\text { Acrocephalus } \\
\text { gracilirostris }\end{array}$ & $\begin{array}{l}\text { Lesser Swamp- } \\
\text { Warbler }\end{array}$ & 1 & 6 & 0 & 0 \\
\hline $\begin{array}{l}\text { Alopochen } \\
\text { aegyptiacus }\end{array}$ & Egyptian Goose & 2 & 0 & 2 & 2 \\
\hline $\begin{array}{l}\text { Amadina ery- } \\
\text { throcephala }\end{array}$ & $\begin{array}{l}\text { Red-headed } \\
\text { Finch }\end{array}$ & 9 & 1 & 16 & 1 \\
\hline $\begin{array}{l}\text { Amadina } \\
\text { fasciata }\end{array}$ & $\begin{array}{l}\text { Cut-throat } \\
\text { Finch }\end{array}$ & 1 & 0 & 4 & 0 \\
\hline $\begin{array}{r}\text { Amandava } \\
\text { subflava }\end{array}$ & $\begin{array}{l}\text { Orange- } \\
\text { breasted } \\
\text { Waxbill }\end{array}$ & 3 & 3 & 0 & 1 \\
\hline $\begin{array}{c}\text { Amblyospiza } \\
\text { albifrons }\end{array}$ & $\begin{array}{l}\text { Thick-billed } \\
\text { Weaver }\end{array}$ & 3 & 20 & 8 & 0 \\
\hline $\begin{array}{l}\text { Anthus } \\
\quad \text { cinnamomeus }\end{array}$ & African Pipit & 7 & 14 & 0 & 2 \\
\hline $\begin{array}{l}\text { Anthus } \\
\quad \text { leucophrys }\end{array}$ & $\begin{array}{l}\text { Plain-backed } \\
\text { Pipit }\end{array}$ & 2 & 6 & 0 & 0 \\
\hline Apus affinis & Little Swift & 1 & 0 & 0 & 2 \\
\hline $\begin{array}{l}\text { Ardea } \\
\quad \text { melanocephala }\end{array}$ & $\begin{array}{l}\text { Black-headed } \\
\text { Heron }\end{array}$ & 1 & 1 & 0 & 0 \\
\hline $\begin{array}{l}\text { Bostrychia } \\
\text { hagedash }\end{array}$ & Hadeda Ibis & 23 & 2 & 57 & 27 \\
\hline $\begin{array}{r}\text { Bradypterus } \\
\text { baboecala }\end{array}$ & $\begin{array}{l}\text { Little } \\
\text { Rush-Warbler }\end{array}$ & 1 & 1 & 0 & 0 \\
\hline $\begin{array}{l}\text { Burhinus } \\
\text { capensis }\end{array}$ & $\begin{array}{l}\text { Spotted } \\
\text { Thick-knee }\end{array}$ & 3 & 3 & 1 & 0 \\
\hline $\begin{array}{l}\text { Chalcomitra } \\
\text { amethystina }\end{array}$ & $\begin{array}{l}\text { Amethyst } \\
\text { Sunbird }\end{array}$ & 11 & 2 & 8 & 4 \\
\hline Cinnyris talatala & $\begin{array}{l}\text { White-bellied } \\
\text { Sunbird }\end{array}$ & 20 & 0 & 40 & 16 \\
\hline $\begin{array}{l}\text { Cisticola } \\
\quad \text { aridulus }\end{array}$ & Desert Cisticola & 1 & 1 & 0 & 0 \\
\hline $\begin{array}{l}\text { Cisticola } \\
\quad \text { fulvicapillus }\end{array}$ & Neddicky & 4 & 5 & 0 & 0 \\
\hline $\begin{array}{l}\text { Cisticola } \\
\text { juncidis }\end{array}$ & Zitting Cisticola & 2 & 2 & 0 & 2 \\
\hline Cisticola lais & $\begin{array}{l}\text { Wailing } \\
\text { Cisticola }\end{array}$ & 1 & 2 & 0 & 0 \\
\hline Cisticola textrix & Cloud Cisticola & 1 & 1 & 0 & 0 \\
\hline $\begin{array}{l}\text { Cisticola } \\
\text { tinniens }\end{array}$ & $\begin{array}{l}\text { Levaillant's } \\
\text { Cisticola }\end{array}$ & 2 & 9 & 0 & 0 \\
\hline Colius striatus & $\begin{array}{l}\text { Speckled } \\
\text { Mousebird }\end{array}$ & 6 & 0 & 10 & 13 \\
\hline Columba guinea & $\begin{array}{l}\text { Speckled } \\
\text { Pigeon }\end{array}$ & 15 & 4 & 16 & 31 \\
\hline Columba livia & Rock Dove & 16 & $\mathbf{0}$ & 20 & 959 \\
\hline Corvus albus & Pied Crow & 2 & 2 & 3 & 0 \\
\hline $\begin{array}{l}\text { Corythaixoides } \\
\text { concolor }\end{array}$ & $\begin{array}{l}\text { Grey } \\
\text { Go-away-bird }\end{array}$ & 19 & 0 & 43 & 24 \\
\hline Cossypha caffra & $\begin{array}{l}\text { Cape } \\
\text { Robin-Chat }\end{array}$ & 14 & 2 & 9 & 11 \\
\hline $\begin{array}{c}\text { Cypsiurus } \\
\text { parvus }\end{array}$ & $\begin{array}{l}\text { African } \\
\text { Palm-Swift }\end{array}$ & 4 & 0 & 5 & 2 \\
\hline $\begin{array}{l}\text { Dicrurus } \\
\text { adsimilis }\end{array}$ & $\begin{array}{l}\text { Fork-tailed } \\
\text { Drongo }\end{array}$ & 1 & 4 & 0 & 0 \\
\hline
\end{tabular}

Appendix A. (Continued)

\begin{tabular}{|c|c|c|c|c|c|}
\hline Species & $\begin{array}{l}\text { Species } \\
\text { common name }\end{array}$ & SUM & Semi-urban & Suburban & Urba \\
\hline $\begin{array}{l}\text { Dryoscopus } \\
\text { cubla }\end{array}$ & $\begin{array}{l}\text { Black-backed } \\
\text { Puffback }\end{array}$ & 2 & 0 & 1 & 2 \\
\hline $\begin{array}{l}\text { Elanus } \\
\quad \text { caeruleus }\end{array}$ & $\begin{array}{l}\text { Black- } \\
\text { shouldered } \\
\text { Kite }\end{array}$ & 3 & 5 & 0 & 0 \\
\hline Euplectes orix & $\begin{array}{l}\text { Southern Red } \\
\text { Bishop }\end{array}$ & 14 & 47 & 16 & 15 \\
\hline $\begin{array}{c}\text { Euplectes } \\
\text { progne }\end{array}$ & $\begin{array}{l}\text { Long-tailed } \\
\text { Widowbird }\end{array}$ & 4 & 8 & 0 & 0 \\
\hline $\begin{array}{l}\text { Eupodotis } \\
\text { afraoides }\end{array}$ & $\begin{array}{l}\text { Northern Black } \\
\text { Korhaan }\end{array}$ & 1 & 1 & 0 & 0 \\
\hline $\begin{array}{l}\text { Francolinus lev- } \\
\text { aillantoides }\end{array}$ & $\begin{array}{l}\text { Orange River } \\
\text { Francolin }\end{array}$ & 2 & 8 & 0 & 0 \\
\hline Fulica cristata & $\begin{array}{l}\text { Red-knobbed } \\
\text { Coot }\end{array}$ & 1 & 4 & 0 & 0 \\
\hline $\begin{array}{l}\text { Gallinula } \\
\text { chloropus }\end{array}$ & $\begin{array}{l}\text { Common } \\
\text { Moorhen }\end{array}$ & 1 & 3 & 0 & 0 \\
\hline $\begin{array}{l}\text { Hirundo } \\
\text { albigularis }\end{array}$ & $\begin{array}{l}\text { White-throated } \\
\text { Swallow }\end{array}$ & 3 & 1 & 2 & 0 \\
\hline $\begin{array}{l}\text { Hirundo } \\
\text { dimidiata }\end{array}$ & $\begin{array}{l}\text { Pearl-breasted } \\
\text { Swallow }\end{array}$ & 1 & 1 & 0 & 0 \\
\hline Hirundo fuligula & Rock Martin & 5 & 0 & 0 & 6 \\
\hline Jynx ruficollis & $\begin{array}{l}\text { Red-throated } \\
\text { Wryneck }\end{array}$ & 2 & 2 & 1 & 0 \\
\hline $\begin{array}{l}\text { Lagonosticta } \\
\text { rhodopareia }\end{array}$ & $\begin{array}{l}\text { Jameson's } \\
\text { Firefinch }\end{array}$ & 1 & 0 & 0 & 3 \\
\hline $\begin{array}{l}\text { Lamprotornis } \\
\text { nitens }\end{array}$ & $\begin{array}{l}\text { Cape Glossy } \\
\text { Starling }\end{array}$ & 5 & 4 & 3 & 2 \\
\hline $\begin{array}{l}\text { Laniarius } \\
\text { ferrugineus }\end{array}$ & $\begin{array}{l}\text { Southern } \\
\text { Boubou }\end{array}$ & 3 & 0 & 3 & 1 \\
\hline Lanius collaris & Common Fiscal & 20 & 19 & 18 & 8 \\
\hline $\begin{array}{l}\text { Lybius } \\
\text { torquatus }\end{array}$ & $\begin{array}{l}\text { Black-collared } \\
\text { Barbet }\end{array}$ & 7 & 3 & 7 & 2 \\
\hline $\begin{array}{l}\text { Macronyx } \\
\text { capensis }\end{array}$ & Cape Longclaw & 10 & 20 & 0 & 0 \\
\hline $\begin{array}{l}\text { Merops } \\
\text { bullockoides }\end{array}$ & $\begin{array}{l}\text { White-fronted } \\
\text { Bee-eater }\end{array}$ & 1 & 3 & 0 & 0 \\
\hline Mirafra africana & $\begin{array}{l}\text { Rufous-naped } \\
\text { Lark }\end{array}$ & 8 & 12 & 0 & 0 \\
\hline $\begin{array}{l}\text { Motacilla } \\
\text { capensis }\end{array}$ & Cape Wagtail & 19 & 3 & 18 & 13 \\
\hline $\begin{array}{l}\text { Myrmecocichla } \\
\text { formicivora }\end{array}$ & $\begin{array}{l}\text { Ant-eating } \\
\text { Chat }\end{array}$ & 1 & 6 & 0 & 0 \\
\hline $\begin{array}{l}\text { Numida } \\
\text { meleagris }\end{array}$ & $\begin{array}{l}\text { Helmeted } \\
\text { Guineafowl }\end{array}$ & 3 & 17 & 0 & 0 \\
\hline $\begin{array}{c}\text { Oenanthe } \\
\text { pileata }\end{array}$ & $\begin{array}{l}\text { Capped } \\
\text { Wheatear }\end{array}$ & 6 & 23 & 0 & 0 \\
\hline $\begin{array}{l}\text { Onychognathus } \\
\text { morio }\end{array}$ & $\begin{array}{l}\text { Red-winged } \\
\text { Starling }\end{array}$ & 2 & 0 & 0 & 12 \\
\hline Oriolus larvatus & $\begin{array}{l}\text { Black-headed } \\
\text { Oriole }\end{array}$ & 2 & 0 & 1 & 1 \\
\hline $\begin{array}{l}\text { Ortygospiza } \\
\text { atricollis }\end{array}$ & $\begin{array}{l}\text { African } \\
\text { Quailfinch }\end{array}$ & 3 & 12 & 0 & 0 \\
\hline Passer diffusus & $\begin{array}{l}\text { Southern } \\
\text { Grey-headed } \\
\text { Sparrow }\end{array}$ & 15 & 32 & 29 & 4 \\
\hline $\begin{array}{l}\text { Passer } \\
\text { domesticus }\end{array}$ & $\begin{array}{l}\text { House } \\
\text { Sparrow }\end{array}$ & 19 & 1 & 60 & 88 \\
\hline $\begin{array}{l}\text { Passer } \\
\text { melanurus }\end{array}$ & Cape Sparrow & 28 & 59 & 170 & 60 \\
\hline $\begin{array}{l}\text { Phoeniculus } \\
\text { purpureus }\end{array}$ & $\begin{array}{l}\text { Green } \\
\text { Wood-Hoopoe }\end{array}$ & 1 & 0 & 3 & 0 \\
\hline Ploceus capensis & Cape Weaver & 2 & 0 & 4 & 0 \\
\hline Ploceus velatus & $\begin{array}{l}\text { Southern } \\
\text { Masked- } \\
\text { Weaver }\end{array}$ & 34 & 46 & 97 & 67 \\
\hline $\begin{array}{l}\text { Porphyrio } \\
\text { madgas- } \\
\text { cariensis }\end{array}$ & $\begin{array}{l}\text { African Purple } \\
\text { Swamphen }\end{array}$ & 1 & 1 & 0 & 0 \\
\hline Prinia flavicans & $\begin{array}{l}\text { Black-chested } \\
\text { Prinia }\end{array}$ & 5 & 5 & 0 & 6 \\
\hline Prinia subflava & $\begin{array}{l}\text { Tawny-flanked } \\
\text { Prinia }\end{array}$ & 2 & 2 & 0 & 0 \\
\hline $\begin{array}{r}\text { Psittacula } \\
\text { krameri }\end{array}$ & $\begin{array}{l}\text { Rose-ringed } \\
\text { Parakeet }\end{array}$ & 1 & $\mathbf{0}$ & 3 & $\mathbf{0}$ \\
\hline
\end{tabular}




\begin{tabular}{|c|c|c|c|c|c|}
\hline Species & $\begin{array}{l}\text { Species } \\
\text { common name }\end{array}$ & SUM & Semi-urban & Suburban & Urban \\
\hline $\begin{array}{l}\text { Pternistes } \\
\text { swainsonii }\end{array}$ & $\begin{array}{l}\text { Swainson's } \\
\text { Spurfowl }\end{array}$ & 4 & 11 & 0 & 0 \\
\hline $\begin{array}{l}\text { Pycnonotus } \\
\text { tricolor }\end{array}$ & $\begin{array}{l}\text { Dark-capped } \\
\text { Bulbul }\end{array}$ & 35 & 16 & 102 & 51 \\
\hline Pytilia melba & $\begin{array}{l}\text { Green-winged } \\
\text { Pytilia }\end{array}$ & 1 & 0 & 0 & 1 \\
\hline $\begin{array}{l}\text { Saxicola } \\
\quad \text { torquatus }\end{array}$ & $\begin{array}{l}\text { African } \\
\text { Stonechat }\end{array}$ & 4 & 13 & 0 & 0 \\
\hline $\begin{array}{l}\text { Serinus } \\
\quad \text { atrogularis }\end{array}$ & $\begin{array}{l}\text { Black-throated } \\
\text { Canary }\end{array}$ & 5 & 4 & 3 & 3 \\
\hline Serinus gularis & $\begin{array}{l}\text { Streaky-headed } \\
\text { Seedeater }\end{array}$ & 10 & 4 & 10 & 12 \\
\hline $\begin{array}{l}\text { Serinus } \\
\quad \text { mozambicus }\end{array}$ & $\begin{array}{l}\text { Yellow-fronted } \\
\text { Canary }\end{array}$ & 1 & 0 & 0 & 3 \\
\hline Sigelus silens & $\begin{array}{l}\text { Fiscal } \\
\text { Flycatcher }\end{array}$ & 3 & 0 & 5 & 1 \\
\hline $\begin{array}{l}\text { Spermestes } \\
\text { cucullatus }\end{array}$ & $\begin{array}{l}\text { Bronze } \\
\text { Mannikin }\end{array}$ & 5 & 0 & 21 & 23 \\
\hline Spreo bicolor & Pied Starling & 1 & 15 & 0 & 0 \\
\hline $\begin{array}{l}\text { Streptopelia } \\
\text { capicola }\end{array}$ & $\begin{array}{l}\text { Cape } \\
\text { Turtle-Dove }\end{array}$ & 23 & 24 & 109 & 16 \\
\hline $\begin{array}{l}\text { Streptopelia } \\
\quad \text { semitorquata }\end{array}$ & Red-eyed Dove & 28 & 29 & 74 & 30 \\
\hline $\begin{array}{l}\text { Streptopelia } \\
\text { senegalensis }\end{array}$ & Laughing Dove & 31 & 16 & 120 & 73 \\
\hline $\begin{array}{l}\text { Struthio } \\
\quad \text { camelus }\end{array}$ & $\begin{array}{l}\text { Common } \\
\text { Ostrich }\end{array}$ & 3 & 8 & 0 & 0 \\
\hline $\begin{array}{r}\text { Telophorus } \\
\text { zeylonus }\end{array}$ & Bokmakierie & 6 & 12 & 2 & 0 \\
\hline $\begin{array}{l}\text { Trachyphonus } \\
\text { vaillantii }\end{array}$ & Crested Barbet & 11 & 1 & 15 & 2 \\
\hline $\begin{array}{l}\text { Turdoides } \\
\text { jardineii }\end{array}$ & $\begin{array}{l}\text { Arrow-marked } \\
\text { Babbler }\end{array}$ & 1 & 0 & 0 & 3 \\
\hline Turdus smithi & Karoo Thrush & 20 & 0 & 29 & 32 \\
\hline Upupa africana & African Hoopoe & 6 & 2 & 8 & 0 \\
\hline $\begin{array}{r}\text { Uraeginthus } \\
\text { angolensis }\end{array}$ & Blue Waxbill & 2 & 0 & 0 & 11 \\
\hline $\begin{array}{r}\text { Urocolius } \\
\text { indicus }\end{array}$ & $\begin{array}{l}\text { Red-faced } \\
\text { Mousebird }\end{array}$ & 7 & 0 & 10 & 7 \\
\hline $\begin{array}{l}\text { Vanellus } \\
\text { armatus }\end{array}$ & $\begin{array}{l}\text { Blacksmith } \\
\text { Lawping }\end{array}$ & 7 & 6 & 9 & 1 \\
\hline $\begin{array}{l}\text { Vanellus } \\
\text { coronatus }\end{array}$ & $\begin{array}{l}\text { Crowned } \\
\text { Lapwing }\end{array}$ & 24 & 68 & 59 & 51 \\
\hline $\begin{array}{l}\text { Vanellus } \\
\text { senegallus }\end{array}$ & $\begin{array}{l}\text { African Wattled } \\
\text { Lapwing }\end{array}$ & 3 & 6 & 0 & 0 \\
\hline Zosterops virens & $\begin{array}{l}\text { Cape } \\
\text { White-eye }\end{array}$ & 21 & 2 & 50 & 47 \\
\hline
\end{tabular}

\section{References}

Anon., 2001. Census 2001: key results. Statistics South Africa, Pretoria.

Bibby, C.J., Burgess, N.D., Hill, D.A., 1992. Bird Census Techniques. Academic Press, London.

Birdlife International, 2004. State of the World's Birds 2004: Indicators for Our Changing World. Birdlife International, Cambridge.

Blackburn, T.M., Duncan, R.P., 2001. Establishment patterns of exotic birds are constrained by non-random patterns in introduction. J. Biogeogr. 28, 927-939.

Blair, R., 1996. Land use and avian species diversity along an urban gradient. Ecol. Appl. 6, 506-519.

Blair, R., 1999. Birds and butterflies along an urban gradient: surrogate taxa for assessing biodiversity? Ecol. Appl. 9, 164-170.

Blair, R., 2001. Creating a homogeneous avifauna. In: Marzluff, J.M., Bowman, R., Donnelly, R. (Eds.), Avian Ecology and Conservation in an Urbanizing World. Kluwer Academic Publishers, Boston, pp. 459-486.

Blair, R., 2004. The effects of urban sprawl on birds at multiple levels of biological organization. Ecol. Soc. 9, 2.

Bowman, R., Marzluff, J.M., 2001. Integrating avian ecology into emerging paradigms in urban ecology. In: Marzluff, J.M., Bowman, R., Donnelly, R. (Eds.), Avian Conservation and Ecology in an Urbanizing World. Springer, New York, pp. 569578.

Buckland, S.T., Anderson, D.R., Burnham, K.P., Laake, J.L., 1993. Distance Sampling: Estimating Abundance of Biological Populations. Chapman and Hall, London.

Chapin III, F.S., Zavaleta, E.S., Eviner, V.T., Rosamond, L.N., et al., 2000. Consequences of changing biodiversity. Nature 405, 234-242.

Cincotta, R.P., Wisnewski, J., Engelman, R., 2000. Human-population in the biodiversity hotspots. Nature 404, 990-992.
Clergeau, P., Savard, J.L., Mennechez, G., Falardeau, G., 1998. Bird abundance and diversity along and urban-rural gradient: a comparative study between two cities on different continents. Condor 100, 413-425.

Clergeau, P., Croci, S., Jokimäki, J., Kaisanlahti-Jokimäki, M.-L., Dinetti, M., 2006. Avifauna homogenisation by urbanisation: analysis at different European latitudes. Biol. Conserv. 127, 336-344.

Coleman, B.D., 1981. On random placement and species-area relations. Math. Biosci. 54, 191-215.

Colwell, R.K., 2005. EstimateS 7.5 User's Guide. Available from http://viceroy.eeb. uconn.edu/estimates (last access date: 10 July 2008).

Colwell, R.K., Mao, C.X., Chang, J., 2004. Interpolating, extrapolating, and comparing incidence-based species accumulation curves. Ecology 85, 27172727.

Crooks, K.R., Suarez, A.V., Bolger, D.T., 2004. Avian assemblages along a gradient of urbanization in a highly fragmented landscape. Biol. Conserv. 115, 451-462.

Duncan, R.P., Blackburn, T.M., Sol, D., 2003. The ecology of bird introductions. Annu. Rev. Ecol. Syst. 34, 71-98.

Feare, C., Craig, A., 1998. Starlings and Mynas. Christopher Helm, London.

Fernandez-Juricic, E., 2001. Avian spatial segregation at edges and interiors of urban parks in Madrid, Spain. Biodivers. Conserv. 10, 1303-1316.

Fleischmann, K., 1997. Invasion of alien woody plants on the islands of Mahé and Silhouette, Seychelles. J. Veg. Sci. 8, 5-12.

Gotelli, N.J., Colwell, R.K., 2001. Quantifying biodiversity: procedures and pitfalls in the measurement and comparison of species richness. Ecol. Lett. 4, 379391.

Harrison, J.A., Allan, D.G., Underhill, L.G., Herremans, M., Tree, A.J., Parker, V., Brown, C.J., 1997. The Atlas of Southern African Birds. BirdLife South Africa, Johannesburg.

Hockey, P.A.R., Dean, W.R.J., Ryan, P.G., 2005. Roberts-Birds of Southern Africa, seventh ed. The Trustees of the John Voelcker Bird Book Fund, Cape Town.

Holzapfel, C., Levin, N., Hatzofe, O., Kark, S., 2006. Colonisation of the Middle East by the invasive Common Myna Acridotheres tristis L., with special reference to Israel. Sandgrouse 28, 44-51.

Kark, S., Iwaniuk, A., Schalimtzek, A., Banker, E., 2007. Living in the city: can anyone become an 'urban exploiter'? J. Biogeogr. 34, 638-651.

Kannan, R., James, D.A., 2001. Common Myna, Acridotheres tristis. In: Poole, A., Gill F. (Eds.), The Birds of North America, No. 583. The Birds of North America Inc. Philadelphia.

Koenig, W.D., 2003. European starlings and their effect on native cavity-nesting birds Conserv. Biol. 17, 1134-1140.

Komdeur, J., 1996. Breeding of the Seychelles Magpie Robin Copsychus sechellarum and implications for its conservation. IBIS 138, 485-498.

Lim, H.C., Sodhi, N.S., 2004. Responses of avian guilds to urbanization in a tropical city. Landsc. Urban Plan. 66, 199-215.

Liversidge, R., 1975. Beware the exotic bird. Bokmakierie 27, 86-87.

Lockwood, J.L., McKinney, M.L., 2002. Biotic Homogenization. Kluwer Academic Publishers, New York, NY

Longino, J.T., Coddington, J., Colwell, R.K., 2002. The ant fauna of a tropical rain forest: estimating species richness three different ways. Ecology 83, 689-702.

Low, A.B., Rebelo, A.G., 1996. Vegetation of South Africa, Lesotho and Swaziland. Department of Environmental Affairs and Tourism, Pretoria.

Lowe, S., Browne, M., Boudjelas, S., De Poorter, M., 2000. 100 of the world's worst invasive alien species. A selection from the Global Invasive Species Database. The Invasive Species Specialist Group (ISSG), a specialist group of the Species Survival Commission (SSC) of the World Conservation Union (IUCN), Auckland.

Maestas, J.D., Knight, R.L., Gilgert, W.C., 2003. Biodiversity across a rural land-use gradient. Conserv. Biol. 17, 1425-1434.

Magurran, A.E., 2004. Measuring Biological Diversity, first ed. Blackwell Publishing, Malden.

Marais, E., 2004. Get listing! Update on the PCC/BiG until 24 August 2004. Laniarius $94,20$.

Matthews, S., Brandt, K., 2004. Africa Invaded: The growing danger of invasive alien species. Global Invasive Species Programme. Available at: http://www.gisp.org casestudies/showcasestudy.asp?id=64\&MyMenultem=casestudies\&worldmap= \&country= (last access date: 5 May 2009).

Matthews, S., Brandt, K., 2006. South America Invaded: The growing danger of invasive alien species. Global Invasive Species Programme. Available at: http://www. gisp.org/casestudies/showcasestudy.asp?id=274\&MyMenultem=casestudies\& worldmap $=\&$ country (last access date: 5 May 2009).

McKinney, M.L., 2002. Urbanization, biodiversity, and conservation. Bioscience 52 883-890.

McKinney, M.L., 2006. Urbanization as a major cause of biotic homogenization. Biol Conserv. 127, 247-260.

O'Brien, E.M., Field, R., Whittaker, R.J., 2000. Climatic gradients in woody plant (tree and shrub) diversity: water-energy dynamics, residual variation, and topography. Oikos 89, 588-600.

Peacock, D.S., van Rensburg, B.J., Robertson, M.P., 2007. The distribution and spread of the invasive alien common myna, Acridotheres tristis L. (Aves: Sturnidae), in southern Africa. S. Afr. J. Sci. 103, 465-473.

Pell, A.S., Tidemann, C.R., 1997. The ecology of the common myna in urban nature reserves in the Australian Capital Territory. EMU 97, 141-149.

Reino, L.M., Silva, T., 1996. Distribution and expansion of common waxbill Estrilda astrild in Portugal. In: Holmes, J.S., Simons, J.R. (Eds.), The Introduction and Naturalization of Birds. HMSO, London, pp. 103-106.

Richardson, D.M., Pyšek, P., 2008. Fifty years of invasion ecology-the legacy of Charles Elton. Divers. Distrib. 14, 161-168. 
Schulze, R.E., 1997. Climate. In: Cowling, R.M., Richardson, D.M., Pierce, S.M. (Eds.), Vegetation of Southern Africa. Cambridge University Press, Cambridge, pp. 21-41.

Shochat, E., Warren, P.S., Faeth, S.H., McIntyre, N.E., Hope, D., 2006. From patterns to emerging processes in mechanistic urban ecology. TREE 4, 186-191.

Smith, K.W., 2005. Has the reduction in nest-site competition from Starlings Sturnus vulgaris been a factor in the recent increase of Great Spotted Woodpecker Dendrocopos major numbers in Britain?: capsule A national decline in Starling numbers and the reduction in nest-site competition may have contributed to the increase in nest success, numbers and habitat distribution of the Great Spotted Woodpecker in Britain. Bird Study 52, 307-313.

Tarboton, W.R., Kemp, M.J., Kemp, A.C., 1987. Birds of the Transvaal. Transvaal Museum, Pretoria.

Thomas, L., Laake, J.L., Strindberg, S., Marques, F.F.C., Buckland, S.T., Borchers, D.L., Anderson, D.R., Burnham, K.P., Hedley, S.L., Pollard, J.H., Bishop, J.R.B Marques, T.A., 2005. Distance 5.0. Release Beta 5. Research Unit for Wildlife
Population Assessment, University of St. Andrews, UK, http://www.ruwpa.stand.ac.uk/distance/(last access date: 10 July 2008).

van Rensburg, B.J., Chown, S.L., Gaston, K.J., 2002. Species richness, environmental correlates, and spatial scale: a test using South African birds. Am. Nat. 159, 566-577.

Yap, C.A., Sodhi, N.S., Brook, B.W., 2002. Roost characteristics of invasive mynas in Singapore. J. Wildlife Manage. 66, 1118-1127.

Berndt J. van Rensburg is interested in human impacts on biodiversity and macroecology, especially in southern Africa, and the conservation implications thereof.

Derick S. Peacock is interested in all aspects related to bird ecology and taxonomy.

Mark P. Robertson is interested in the spatial distribution of biological invasions and the conservation implications thereof 